\title{
Europejska, Śródziemnomorska i Bliskowschodnia Konferencja Systemów Informacyjnych - EMCIS (Coimbra, Portugalia, 7-8 września 2017 r.)
}

European, Mediterranean and Middle Eastern Conference on Information Systems (EMCIS) to doroczna konferencja naukowa poświęcona problemom badawczym dotyczącym systemów informacyjnych (SI). Konferencja, zainicjowana w 2004 r., gromadzi teoretyków i praktyków zajmujących się technicznymi, organizacyjnymi, ekonomicznymi i społecznymi aspektami technologii informacyjnych. Tegoroczna edycja konferencji, która odbyła się w dniach 7-8 września, zorganizowana została przez Wydział Nauki i Technologii Uniwersytetu w Coimbrze (Faculdade de Ciências e Tecnologia da Universidade de Coimbra) i zgromadziła prelegentów z 32 krajów.

Wykład inauguracyjny pt. Organizational identity and self-awarness: creating convergence between enterprise engineering and organizational design wygłosił prof. José M. Tribolet (Technical University of Lisbon, Portugalia). Właściwa część konferencji odbywała się w trzech równoległych blokach sesji, poświęconych następującym grupom problemów:

- Healthcare Information Systems,

- Management and Organisational Issues in Information Systems,

- Digital Services, Social Media and Digital Collaboration,

- Information Systems Security and Information Privacy Protection,

- Cloud Computing,

- Big Data and Semantic Web,

- e-Government

- IT Governance.

Dodatkowo przeprowadzono: warsztat na temat Computer Security, Vulnerability Exploits and Ethical Hacking oraz panel How to Succeed on your Ph.D.

Najciekawszą częścią konferencji z informatologicznego punktu widzenia były sesje poświęcone problematyce e-government. W jej trakcie przedstawiono pięć referatów spośród zaplanowanych siedmiu.

Muhammad Akmal Javaid (Quaid-i-Azam University, Islamabad, Pakistan) i Muhammad Irfanullah Arfeen z (United Nations University-Operating Unit on Policy Driven Electronic Governance, Guimarães, Portugalia) w swoim wystąpieniu zatytułowanym Impact of eGovernment on Citizen Satisfaction: A Case of Federal Government Agencies in Pakistan przedstawili wyniki badania poziomu satysfakcji użytkowników usług publicznych oferowanych przez instytucje federalne w Pakistanie. Na potrzeby badania przyjęli pięć hipotez badawczych, w ramach których założyli, że pozytywny wpływ na poziom satysfakcji użytkowników mają: 1) architektura stron internetowych, 2) zaufanie do elektronicznych usług publicznych, 3) e-readiness (którą rozumieją węziej niż przyjęto w Networked Readiness Index, ponieważ ograniczają się tylko do infrastruktury), 4) jakość elektronicznych usług publicznych oraz 5) ich poziom zabezpieczeń. W badaniu wykorzystano kwestionariusz ankiety elektronicznej oraz przeprowadzono wywiady pogłębione (zarówno wśród użytkowników usług, jak i pracowników instytucji federalnych). W konkluzjach autorzy przedstawili zalecenia dla zwiększenia poziomu satysfakcji użytkowników z korzystania z wybranych usług

W prezentacji Is e-Government Serving Companies or Vice-Versa? Anton Manfreda (University of Ljubljana, Słowenia) położył nacisk na fakt, że e-government to nie tylko informatyzacja sektora publicznego, ale również biznesowy model zarządzania procesami. Bazując na studium przypadku 
anonimowej firmy zarządzającej odpadami w Europie Środkowej, omówił wybrane koncepcje digitalizacyjne oraz ich wpływ na wzrost efektywności organizacji.

W wystąpieniu pod tytułem Public Participation and Regulatory Public Policies: An Assessment from the Perspective of Douglasian Cultural Theory, przygotowanym przez zespół w składzie Gustavo C. Garcia (Pontifical Catholic University of Rio de Janeiro, Brazylia), Flavio Saab, Jonathan S. Pereira i Paulo Bermejo (University of Brasilia, Brazylia), przedstawiono ewaluację publicznych konsultacji w kontekście zaangażowania grup interesariuszy reprezentujących różne punkty widzenia. Prelegenci w przeprowadzonym badaniu wykorzystali socjologiczną cultural theory Mary Douglas, która dzieli ludzi na cztery grupy: indywidualistów, hierarchistów, fatalistów i egalitarian. Za pomocą tej teorii przeanalizowali wpływ konsultacji społecznych na tworzenie polityk w zakresie regulacji rynku żywności w Brazylii. Jak wskazują ich badania, proces konsultacji angażuje jedynie niektóre grupy interesariuszy (egalitarian i hierarchistów, w niewielkim stopniu również indywidualistów), a instytucje publiczne powinny kłaść większy nacisk na pluralizm pozyskiwanych opinii. Referat ten otrzymał Best Paper Award w trakcie uroczystej kolacji kończącej pierwszy dzień obrad.

Mariusz Luterek $\mathrm{z}$ Uniwersytetu Warszawskiego, w referacie $e$-Government and e-Inclusion. The Role of the Public Libraries zaprezentował wyniki badania opinii bibliotekarzy w zakresie możliwości pośredniczenia przez biblioteki publiczne w dostępie do e-government w Polsce. Na potrzeby zaprezentowanego badania przyjęto hipotezę, iż biblioteki publiczne mogą pełnić funkcję pośrednika w dostępie do informacji i usług publicznych dla obywateli. Wyniki badania ankietowego, przedstawione w kontekście systemów pośredniczenia w dostępie do informacji publicznej i usług publicznych online w Wielkiej Brytanii, Francji, Danii i USA, pokazały, że poziom zainteresowania pełnieniem funkcji pośredniczącej w tym zakresie wśród bibliotekarzy w Polsce, niestety, jest niski.

Wreszcie, Pedro de Barros Leal Pinheiro Marino, Grazielle Isabele Cristina Silva Sucupira, Wender Rodrigues de Siqueira oraz Paulo Bermejo (Universidade de Brasília, Brazylia) w referacie Public Transparency in the Brazilian Context: An Integrative Review przedstawili wyniki badania bibliometrycznego w obszarze przejrzystości sektora publicznego w Brazylii. Dla zidentyfikowania różnych form transparentności, zakładanych i osiągniętych rezultatów, przeanalizowali literaturę z lat 1990-2017, dostępną w pięciu bazach elektronicznych: Scielo, Spell, Redalyc, Web of Science, oraz Science Direct. Autorom udało się zidentyfikować trzy typy transparentności: administracyjną, budżetową oraz polityczną. Uzyskane wyniki wskazują na zdecydowaną przewagę publikacji o charakterze empirycznym, prezentujących wyniki badań ilościowych.

Z punktu widzenia zainteresowań informatologów na uwagę zasługują również referaty zaprezentowane w ramach sesji Digital Services, Social Media and Digital Collaboration, w której przedstawiono sześć referatów. W pierwszym, zatytułowanym MOOCS Potential for Democratizing Education: An analysis from the perspective of access to technology, Valéria F Moura, Cesar A Souza, José D Oliveira Neto oraz Adriana B N Viana (University of São Paulo, Brazylia) przeanalizowali potencjał MOOC jako narzędzia demokratyzującego jakość edukacji. W przeprowadzonym badaniu sondażowym zebrali informacje o doświadczeniach 4784 studentów z 27 uczelni.

Następnie Jooyeon Won i DongBack Seo (Chungbuk National University, Cheongju, Republika Korei) w referacie Relationship between self-disclosure and cyberbullying on SNSs, wykorzystując socjologiczną teorię wymiany, na przykładzie Korei Południowej omówili zagrożenia wynikającego z nadmiernej otwartości użytkowników w sieciach społecznościowych. Z kolei Petr Štěpánek, Mouzhi Ge i Leonard Walletzký (Masaryk University, Brno, Czechy), w wystąpieniu IT-enabled Digital Service Design Principles - Lessons Learned from Digital Cities przeanalizowali rozwiązania zastosowane w Barcelonie w kontekście możliwości ich zastosowania w innych miastach. Warto zwrócić uwagę, że referat ten wywołał gorącą dyskusję dotyczącą różnicy pomiędzy koncepcjami digital city oraz smart city.

W ostatniej części sesji wygłoszono dwa referaty. Bruno Faria i Rui Dinis Sousa (University of Minho, 4804-533 Guimarães, Portugalia), w wystąpieniu Enterprise Social Networks Goals and Success 
Measurement: Evidence from a Multinational Organization omówili wpływ narzędzia Yummer (pełni ono podobne funkcje do ogólnodostępnego serwisu LinkedIn, ogranicza się jednak do grona pracowników danej organizacji oraz oferuje dodatkowe rozwiązania dla wsparcia pracy grupowej), udostępnionego w 2014 r. przez Microsoft, na działanie organizacji. Natomiast Christer Carlsson, Anna Sell, Camilla Walden, Pirkko Walden (Åbo Akademi University, Turku, Finlandia), Siw Lundqvist oraz Leif Marcusson (Linneus University, Kalmar, Szwecja) zaprezentowali referat pt. Go Vendla Go! Creating a Digital Coach for the Young Elderly. Omówili w nim wyniki realizowanego od 2014 r. projektu, którego celem jest aktywizacja osób z grupy 75+ przy wykorzystaniu dedykowanego elektronicznego trenera nazwanego Vendla.

Kolejna edycja konferencji, zaplanowana na 4-5 października 2018 r., odbędzie się w Limassol na Cyprze.

Mariusz Luterek

Katedra Informatologii

Wydziat Dziennikarstwa, Informacji i Bibliologii

Uniwersytet Warszawski

\section{Europejska Konferencja Edukacji Informacyjnej}

\section{(Saint-Malo, Francja, 18-21 września 2017 r.)}

W dniach 18-21 września 2016 r. w Saint-Malo odbyła się 5. edycja European Conference on Information Literacy (ECIL), zorganizowana przez Wydział Nauk o Informacji i Komunikacji Uniwersytetu w Zagrzebiu oraz Wydział Zarządzania Informacją Uniwersytetu Hacettepe w Ankarze, we współpracy z Information Literacy Association (InLitAs).

W konferencji uczestniczyło 300 osób z 50 krajów. ECIL to, obok angielskiego LILAC, największe i najważniejsze odbywające się w Europie coroczne spotkanie bibliotekarzy i badaczy zajmujących się kompetencjami informacyjnymi i edukacją informacyjną. Podczas czterodniowych obrad odbyło się pięć warsztatów, wygłoszono 211 referatów (w sesjach równoległych), 12 krótkich prezentacji (tzw. pecha-kucha), zaprezentowano 26 posterów, siedem prezentacji z badań doktoranckich, odbyły się cztery dyskusje panelowe. Wybrane referaty zostaną opublikowane w recenzowanym tomie pokonferencyjnym, nakładem wydawnictwa Springer w ramach serii Communications in Computer and Information Science (Kurbanoğlu et al., eds. 2017).

Referaty w sesjach zostały podzielone na 18 bloków tematycznych:

- Information literacy and education,

- Information literacy research,

- Information literacy in school education,

- Information literacy in the workplace,

- Information literacy for different groups,

- Information seeking and information behaviour,

- Information literacy and law,

- Information literacy in higher education,

- Information literacy instruction,

- Research data literacy,

- Information literacy and democracy,

- Science literacy, 